\title{
Eksperimen Numerik Pada Model Optimisasi Perlindungan Banjir Dengan Menggunakan Pendekatan Pemrograman Dinamik
}

\author{
Ghiffaniaz Zahra Fadillah ${ }^{1}$, Diah Chaerani², Juli Rejito ${ }^{3}$ \\ 1,2 Departemen Matematika, Fakultas MIPA, Universitas Padjadjaran, Bandung \\ ${ }^{3}$ Departemen Ilmu Komputer, Fakultas MIPA, Universitas Padjadjaran, Bandung \\ Email : ghiffaniaz12001@mail.unpad.ac.id, d.chaerani@unpad.ac.id,juli.rejito@unpad.ac.id
}

\begin{abstract}
ABSTRAK
Banjir merupakan bencana yang menjadi persoalan penting di seluruh dunia karena banjir terjadi hampir di seluruh negara. Peristiwa banjir disebabkan oleh beberapa faktor, diantaranya akibat curah hujan yang tinggi, pendangkalan, dan sebagainya. Hal ini menyebabkan volume air meningkat dan air meluap dari badan air sehingga merendam daratan di sekitarnya. Banjir memiliki dampak buruk salah satunya yaitu kerusakan, dimana mendorong kearah kerugian material dan non-material. Pada makalah ini dibahas eksperimen numerik pada Model Optimisasi Perlindungan Banjir dimana model ini terdiri dari fungsi biaya investasi eksponensial dan fungsi biaya kerusakan. Eksperimen bertujuan untuk mengetahui kapan dan berapa tinggi badan air yang harus ditinggikan. Pendekatan Pemrograman Dinamik yang digunakan untuk mendapatkan solusi optimal pada eksperimen numerik yaitu metode penyelesaian Masalah StageCoach karena masalahnya yang bertahap dan saling berkaitan satu sama lain. Software Maple digunakan sebagai alat bantu perhitungan.
\end{abstract}

Kata kunci: pencegahan banjir, model optimisasi perlindungan banjir, pemrograman dinamik, masalah stagecoach.

\begin{abstract}
Flood is a disaster that become an important issue worldwide because it occurred in almost all countries. Flood is caused by some factors, they are, heavy rainfall, sedimentation, etc. This is cause water volume increase and water overflows from water body so that it covers the land around there. Flood has a negative impact, that is damage, that involve material and non-material losses. This paper discusses about numerical experiment of the Flood Prevention Optimization Model which is consists of exponential investment cost function and damage cost function. The experiment is aim to know when the time of heightening and how much the height of the water body must be heightened. The Dynamic Programming approach that used in numerical experiment is a method to solve the StageCoach problem because the problem is consist of some stages and related each other. Maple Software is used as the tools to help on numerical experiment.
\end{abstract}

Keywords: flood prevention, optimization model of flood protection, dynamic programming, stagecoach problem.

\section{Pendahuluan}

Peristiwa banjir merupakan bencana yang paling menjadi perhatian dunia karena hampir seluruh negara pernah mengalaminya. Banjir merupakan peristiwa yang terjadi ketika daratan terendam oleh air akibat luapan air. Peristiwa banjir disebabkan oleh beberapa faktor, salah satunya adalah karena volume air di suatu badan air meluap sehingga air keluar dari batasan dan merendam daratan di sekitarnya.

Studi literatur yang dilakukan dalam makalah ini merujuk pada fenomena banjir di Belanda. Pada tahun 1953, terjadi sebuah banjir besar di bagian barat daya Belanda yang membunuh ribuan orang dan menyebabkan kerugian ekonomi yang sangat besar (Eijgenraam et al., 2012). Tentunya hal ini merupakan persoalan besar bagi Pemerintah Belanda. Sebagai reaksi preventif, Pemerintah Belanda membangun sebuah proyek delta yaitu pembangunan infrastruktur tanggul raksasa yang cukup strategis sebagai pertahanan dalam pencegahan banjir. Sejak saat itu D. van Dantzig, ahli statistika Belanda diminta untuk memecahkan masalah keputusan ekonomi mengenai ketinggian tanggul optimal pada Proyek Delta. Van Dantzig mengembangkan analisis cost-benefit pada modelnya, namun model ini masih belum sempurna. 
Oleh sebab itu, pemerintah meminta Eijgenraam, Ruud Brekemans, Dick den Hertog, dan Kees Roos untuk mengembangkan sebuah Model Optimisasi Perlindungan Banjir yang baru.

Pokok bahasan pada makalah ini adalah eksperimen numerik pada Model Optimisasi Perlindungan Banjir yang telah dikembangkan oleh para peneliti Belanda. Eksperimen numerik ini bertujuan untuk mengetahui kapan peninggian tanggul harus dilakukan dan berapa tinggi tanggul yang harus dibangun agar tidak terjadi banjir di daerah sekitar tanggul tersebut. Data yang digunakan pada makalah ini diperoleh dari Hertog \& Roos (2008). Software Maple digunakan sebagai alat bantu perhitungan numerik pada makalah ini.

\section{Metode Penelitian}

Metode penelitian yang digunakan pada makalah ini adalah metode penelitian deskriptif yang mana mencakup penelitian studi kasus dan penelitian perpustakaan dan dokumenter. Pada makalah ini dilakukan metode studi literatur dalam pengumpulan referensi dan data-data yang dibutuhkan. Studi literatur yang digunakan berupa jurnal dan buku yang berbuhubungan dengan masalah perlindungan banjir di Belanda. Data yang digunakan terdiri data sekunder, dimana data diperoleh secara tidak langsung dari Hertog \& Roos (2008).

Berdasarkan eksperimen numerik yang dilakukan, metode yang digunakan untuk menyelesaikannya adalah dengan metode pendekatan pemrograman dinamik yaitu metode penyelesaian masalah StageCoach karena masalahnya yang bertahap dan berkaitan satu sama lain.

\section{Hasil dan Pembahasan}

Pada hasil dan pembahasan dilakukan eksperimen numerik pada Model Optimisasi Pencegahan Banjir dengan menggunakan data dari Hertog \& Roos (2008).

\subsection{Model Optimisasi Perlindungan Banjir}

Model Optimisasi Perlindungan Banjir terdiri dari Fungsi Biaya Kerusakan Tahunan (Damage Cots) dan Fungsi Biaya Investasi Peninggian Tanggul (Investment Cost). Kerugian pertahun $\left(S_{t}\right)$ didefinisikan sebagai hasil kali dari kerugian pada saat $t\left(V_{t}\right)$ dengan peluang terjadinya banjir pertahun $\left(P_{t}\right)$ dimana peluang $P_{t}$ adalah kemungkinan bahwa permukaan air melebihi permukaan tanggul sehingga menyebabkan tanggul hancur. Diasumsikan bahwa banjir tidak terjadi lebih dari sekali pertahun. Pada model ini digunakan distribusi eksponensial karena menghasilkan pendekatan yang baik untuk peluang terjadinya banjir. Kemudian berkenaan dengan kerugian yang diakibatkan oleh banjir, kerugian ini meliputi kerugian materi, non-materi, dan pertumbuhan ekonomi karena pertumbuhan ekonomi berpengaruh pada besarnya biaya kerugian. Sehingga fungsi biaya kerusakan pada model ini melibatkan laju pertumbuhan ekonomi. Maka secara keseluruhan, mengacu pada fungsi dalam jurnal yang ditulis oleh Hertog \& Roos (2008) dan Eijgenraam et al., (2012), Fungsi Harapan Biaya Kerugian yang dinotasikan dengan $E(u, \tau)$ dengan menggunakan analisis cost-benefit dapat ditulis sebagai berikut :

$$
\begin{aligned}
& E(u, \quad)=\frac{S_{0}}{1} e_{k=0} e^{h_{k}}\left(e^{1^{t_{k+1}}} \quad e^{1^{t_{k}}}\right) \\
& \text { di mana } \tau=\left(\begin{array}{c}
t_{0} \\
t_{1} \\
t_{2} \\
\vdots
\end{array}\right) \operatorname{dan} u=\left(\begin{array}{c}
u_{0} \\
u_{1} \\
u_{2} \\
\vdots
\end{array}\right), \\
& \text { dengan } \begin{array}{l}
S_{0}=P_{0} V_{0} \\
=
\end{array} \quad>0 \\
& 1=
\end{aligned}
$$




$$
h_{t}={ }_{i=0}^{k} u_{i}=h_{k} ; t \quad\left[t_{k}, t_{k+1}\right), k=0,1, \ldots
$$

di mana

$$
=+
$$

maka

$$
{ }_{1}=\quad+\quad 1
$$

di mana

$$
\begin{aligned}
& P_{0}=\text { Peluang terjadinya banjir pada saat } \mathrm{t}=0(1 / \text { tahun }) \\
& V_{0}=\text { Kerugian akibat banjir pada saat } t=0 \text { (juta euros) } \\
& \alpha=\text { Parameter distribusi eksponensial untuk permukaan air ekstrim }(1 / \mathrm{cm}) \\
& \eta=\text { Laju kenaikan struktur permukaan air (cm/tahun) } \\
& \gamma=\text { Laju pertumbuhan ekonomi di sekitar tanggul per tahun } \\
& \delta_{1}=\delta_{2}+\rho=\text { Discount rate } \text { untuk fungsi biaya kerugian akibat banjir }(1 / \text { tahun }) \\
& \rho=\text { Risk premium ekonomi makro } \\
& \zeta=\text { Kenaikan kerugian saat peninggian tanggul }(1 / \mathrm{cm}) \\
& \beta=\text { Laju pertumbuhan dari biaya kerusakan } \\
& h_{t}=\text { Tinggi tanggul pada saat } t(\mathrm{~cm}) \\
& u_{t}=\text { Besarnya peninggian yang dilakukan pada saat } t(\mathrm{~cm})
\end{aligned}
$$

Kemudian untuk Fungsi Biaya Investasi Peninggian, digunakan Fungsi Biaya Investasi eksponensial karena cocok dengan data yang ada. Fungsi Biaya Investasi dapat didefinisikan sebagai biaya yang digunakan dalam pembangunan tanggul. Sehingga Biaya investasi bergantung pada ketinggian tanggul. Definisikan biaya investasi yang bergantung pada $u_{k}$ dan perbaharuan tanggul sebelumnya sebagai $I_{k}\left(u^{k}\right)$, dimana $u^{k}$ merupakan notasi dari vektor $\left(u_{0} ; u_{1} ; \ldots ; u_{k}\right)$. Fungsi $I_{k}\left(u^{k}\right)$ berdasarkan model Kees Roos (2009) adalah sebagai berikut :

$$
I_{k}\left(u^{k}\right)=\left(\tilde{\delta}_{0, u_{k}} C+b u_{k}\right) e^{\lambda h_{k}} ; k=0,1, \ldots ; h_{k}=\sum_{i=0}^{k} u_{i}
$$

di mana $C, b$, dan $\lambda$ merupakan konstanta positif dan

$$
\tilde{\delta}_{0, u_{k}}=1-\delta_{0, u_{k}}
$$

$0, u_{k}$ merupakan kronecker delta dimana

Sehingga

$$
\delta_{0, u_{k}}=\left\{\begin{array}{c}
1, u_{k}=0 \\
0, u_{k} \text { lainnya }
\end{array}\right.
$$

$$
\tilde{\delta}_{0, u_{k}}=\left\{\begin{array}{c}
0, u_{k}=0 \\
1, u_{k} \text { lainnya }
\end{array}\right.
$$

Karena adanya kemungkinan muncul laju risk-free diskonto $\left(\delta_{2}\right)$ pada setiap waktu t, maka diberikan laju diskonto pada biaya investasi $I_{k}\left(u^{k}\right)$. Hal ini mempengaruhi variabel terikat yang ada pada biaya investasi, dimana pada awalnya hanya bergantung pada ketinggian tanggul, kemudian setelah dimasukkan laju diskonto menjadi bergantung pada variabel ketinggian dan variabel waktu peninggian. Sehingga biaya investasi yang telah diberikan laju diskonto dapat ditulis sebagai berikut :

$$
I(u, \tau)=\sum_{k=0}^{\infty}\left(\tilde{\delta}_{0, u_{k}} C+b u_{k}\right) e^{\lambda h_{k}-\delta_{2} t_{k}}
$$

Biaya Investasi Peninggian Tanggul ada jika adanya proses peninggian yang dilakukan. Artinya, jika $u_{k}=0$ maka $I(u, \tau)=0$. Sehingga $I(u, \tau)$ ada untuk $u_{k}>0$. Hal ini tentunya berpengaruh pada kronecker delta yang ada. Jika $u_{k}>0$ maka $\tilde{\delta}_{0, u_{k}}=1$. Sehingga Biaya Investasi menjadi : 


$$
I(u, \quad)=\left(C+b u_{k}\right) e^{h_{k}} 2^{t_{k}}
$$

Lalu jika ditinjau dari kedua biaya tersebut, dapat disimpulkan bahwa kedua biaya ini merupakan biaya yang dikeluarkan pada proses pencegahan banjir. Sehingga untuk menyederhanakan fungsi biaya secara keseluruhan, kedua biaya ini dapat digabung dengan operasi penjumlahan yang mana disebut dengan Biaya Total. Notasikan Biaya Total sebagai $f(u, \tau)$, sehingga Biaya Total pada Model Optimisasi Perlindungan Banjir dapat ditulis sebagai berikut

Berdasarkan (3.1) dan (3.13) maka diperoleh

$$
f(u, \quad)=E(u, \quad)+I(u, \quad)
$$

$$
f(u, \tau)=\sum_{k=0}^{\infty}\left[\begin{array}{c}
\left(C+b u_{k}\right) e^{\lambda h_{k}-\delta_{2} t_{k}}+ \\
\frac{S_{0}}{\beta_{1}}\left[e^{-\theta h_{k}}\left(e^{\beta_{1} t_{k+1}}-e^{\beta_{1} t_{k}}\right)\right]
\end{array}\right]
$$

Diperoleh biaya total pada persamaan (3.12). Berdasarkan Analisis Cost-Benefit, kesejahteraan sosial akan meningkat dengan meminimasi biaya total, yang terdiri dari biaya kerusakan dan biaya investasi. Maka diperoleh Model Optimisasi Pencegahan Banjir sebagai berikut

$$
\min \left\{\sum_{k=0}^{\infty}\left[\begin{array}{c}
\left(C+b u_{k}\right) e^{\left(\lambda \sum_{i=0}^{k} u_{i}\right)-\delta_{2} t_{k}}+ \\
\frac{s_{0}}{\beta-\delta_{1}}\left[e^{-\theta \sum_{i=0}^{k} u_{i}}\left(e^{\left(\beta-\delta_{1}\right) t_{k+1}}-e^{\left(\beta-\delta_{1}\right) t_{k}}\right)\right.
\end{array}\right]\right\}
$$

dengan variabel optimisasi $u_{1}, u_{2}, u_{3}, \ldots, u_{K}$ dan $t_{1}, t_{2}, t_{3}, \ldots, t_{K}$.

\subsection{Eksperimen Numerik}

Pencarian solusi optimal untuk Model Optimisasi Perlindungan Banjir dilakukan dengan pendekatan Pemrograman Dinamik, yaitu metode penyelesaian masalah StageCoach karena jenis masalahnya yang bertahap dan berkaitan satu sama lain. Eksperimen numerik dengan menggunakan pemrograman dinamik bertujuan untuk mencari nilai $u$ dan $t$ yang meminimalkan fungsi tujuan, dalam hal ini fungsi tujuannya adalah biaya total.

Definisikan state sebagai pasangan terurut $(t, H)$ dimana $t$ adalah waktu peninggian dengan $t \quad[0, T]$ dan $H$ adalah ketinggian tanggul pada waktu t. Sebut $k$ sebagai stage, $t$ sebagai nomor dari state dan $H$ sebagai tinggi dari state $(t, H)$. State awal dimulai dengan $t=0$ dan $H=H_{0}$, yaitu $\left(0, H_{0}\right)$, dan state pada stage akhir adalah $(T, H)$.

Transisi dapat berjalan dari state $\left(t_{1}, h_{1}\right)$ ke state $\left(t_{2}, h_{2}\right)$ jika $t_{2} \geq t_{1}$ dan $h_{2} \geq h_{1}$. Transisi dari suatu state ke state berikutnya ditandai dengan biaya transisi $c_{t, h_{1}, h_{2}}$. Definisikan $c_{t, h_{1}, h_{2}}=c\left(t, h_{1}, h_{2}\right)$. Maka biaya transisi dapat ditulis sebagai berikut :

$$
\begin{gathered}
c_{t, h_{1}, h_{2}}=c\left(t, h_{1}, h_{2}\right) \\
c_{t, h_{1}, h_{2}}=\left(\tilde{\delta}_{h_{1}, h_{2}} C+b\left(h_{2}-h_{1}\right)\right) e^{\lambda h_{2}-\delta_{2}(t+1)}+E\left(t, t+1, h_{1}\right) \\
\tilde{\delta}_{h_{1}, h_{2}}=0 \text { jika } h_{2}=h_{1} \text { dan } \tilde{\delta}_{h_{1}, h_{2}}=1 \text { jika } h_{2}>h_{1} .
\end{gathered}
$$

Asumsikan bahwa biaya total minimum untuk berpindah dari initial state $(0,0)$ ke state $\left(t, h_{1}\right)$ dinotasikan dengan $K_{t, h_{1}}$. Maka rekursif formula untuk mendapatkan biaya minimum dari setiap state adalah

$$
K_{t+1, h_{2}}=\min _{h_{2} h_{1}}\left(K_{t, h_{1}}+c_{t, h_{1}, h_{2}}\right)
$$

Data yang digunakan untuk perhitungan solusi numerik bersumber pada jurnal Hertog \& Roos (2008). Data yang digunakan dapat dilihat pada Tabel 1 berikut

Tabel 1: Data Tanggul

\begin{tabular}{|l|l|l|l|l|l|}
\hline Sim-bol & Tanggul 10 & Tanggul 11 & Tanggul 15 & Tanggul 16 & Tanggul 22 \\
\hline$C$ & 16.6939 & 42.62 & 125.6422 & 324.6287 & 154.4388 \\
\hline$b$ & 0.6258 & 1.7068 & 1.1268 & 2.1304 & 0.9325 \\
\hline
\end{tabular}




\begin{tabular}{|l|l|l|l|l|l|}
\hline$\lambda$ & 0.0014 & 0 & 0.0098 & 0.01 & 0.0066 \\
\hline$\alpha$ & 0.033027 & 0.032 & 0.0502 & 0.0574 & 0.07 \\
\hline$\eta$ & 0.32 & 0.32 & 0.76 & 0.76 & 0.62 \\
\hline$\zeta$ & 0.003774 & 0.003469 & 0.003764 & 0.002032 & 0.002893 \\
\hline$V_{0}$ & 1564.9 & 1700.1 & 11810.4 & 22656.5 & 9641.1 \\
\hline$P_{0}$ & $1 / 2270$ & $1 / 855$ & $1 / 729$ & $1 / 906$ & $1 / 1802$ \\
\hline$\gamma$ & 0.02 & 0.02 & 0.02 & 0.02 & 0.02 \\
\hline$\delta$ & 0.04 & 0.04 & 0.04 & 0.04 & 0.04 \\
\hline$H_{0}$ & 0 & 0 & 0 & 0 & 0 \\
\hline
\end{tabular}

Sumber: Hertog \& Roos, 2008.

Eksperimen numerik dilakukan dengan pengujian beberapa studi kasus sebagai berikut

Kasus 1:

Dilakukan pembatasan pada $\mathrm{T}$ dan $\mathrm{H}$, dimana $T=\{0,1,2,3,4\}$ tahun dan $H=\{0,100,200,300,400,500,600\} \mathrm{cm}$ dibuat menjadi diskrit. Kemudian diberikan syarat yaitu setiap tahun harus dilakukan peninggian, artinya $u_{k} \neq 0$.

Kasus 2 :

Dilakukan pembatasan pada $\mathrm{T}$ dan $\mathrm{H}$, dimana $T=\{0,5,10,15,20\}$ tahun dan $H=\{0,100,200,300,400,500,600\} \mathrm{cm}$ dibuat menjadi diskrit. Kemudian diberikan syarat yaitu setiap minimum 5 tahun sekali harus dilakukan peninggian, artinya $u_{k} \neq 0$.

Kasus 3 :

Dilakukan pembatasan pada $\mathrm{T}$ dan $\mathrm{H}$, dimana $T=\{0,10,20,30,40\}$ tahun dan $H=\{0,100,200,300,400,500,600\} \mathrm{cm}$ dibuat menjadi diskrit. Kemudian diberikan syarat yaitu setiap minimum 10 tahun sekali harus dilakukan peninggian, artinya $u_{k} \neq 0$.

Kasus 4 :

Dilakukan pembatasan pada $\mathrm{T}$ dan $\mathrm{H}$, dimana $T=\{0,50,100,150,200\}$ tahun dan $H=\{0,100,200,300,400,500,600\} \mathrm{cm}$ dibuat menjadi diskrit. Kemudian diberikan syarat yaitu setiap minimum 50 tahun sekali harus dilakukan peninggian, artinya $u_{k} \neq 0$.

Kasus 5 :

Dilakukan pembatasan pada $T$ dan $H$, dimana $T=\{0,100,200,300,400\}$ tahun dan $H=\{0,100,200,300,400,500,600\} \mathrm{cm}$ dibuat menjadi diskrit. Kemudian diberikan syarat yaitu setiap minimum 100 tahun sekali harus dilakukan peninggian, artinya $u_{k} \neq 0$.

Penyelesaian dilakukan dengan menggunakan pendekatan pemrograman dinamik : Langkah pertama, dibuat path network untuk Model Optimisasi Perlindungan Banjir.

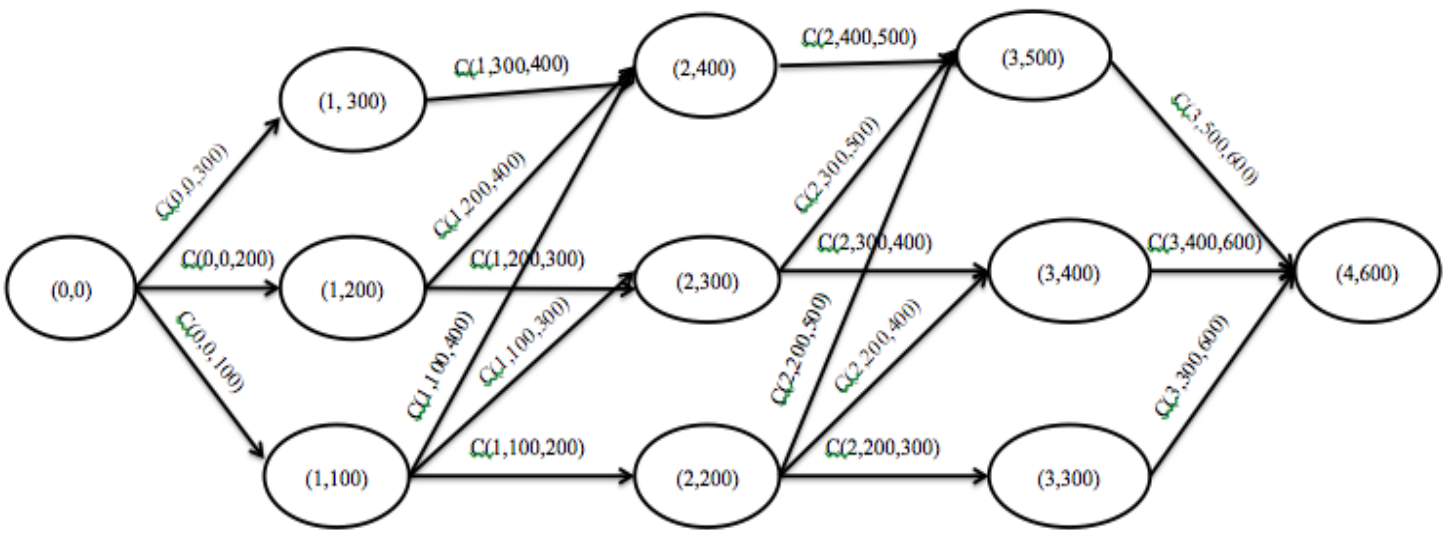

Gambar 1. Path Network Kasus 1 Tanggul 10 untuk ModelOptimisasi Perlindungan Banjir 
Gambar 1: dapat dilihat bahwa masalah pada Gambar 1 dapat dipandang sebagai Masalah StageCoach dalam pendekatan Pemrograman Dinamik karena masalahnya yang bertahap. Maka langkah selanjutnya yaitu menghitung biaya transisi $c\left(t, h_{1}, h_{2}\right)$.

Tabel 2: Nilai Biaya Transisi untuk Kasus 1 Tanggul 10

\begin{tabular}{|c|c|}
\hline \multicolumn{2}{|c|}{ Nilai c untuk $\mathrm{t}=0$ (juta euro) } \\
\hline$c(0,0,100)$ & 88.30 \\
\hline $\mathbf{c}(0,0,200)$ & 181.02 \\
\hline $\mathbf{c}(0,0,300)$ & 299.63 \\
\hline \multicolumn{2}{|c|}{ Nilai c untuk t=1 (juta euro) } \\
\hline$c(1,100,200)$ & 96.86 \\
\hline$c(1,100,300)$ & 199.33 \\
\hline c(1,100,400) & 330.42 \\
\hline$c(1,200,300)$ & 111.38 \\
\hline$c(1,200,400)$ & 299.25 \\
\hline$c(1,300,400)$ & 128.11 \\
\hline \multicolumn{2}{|c|}{ Nilai c untuk $\mathrm{t}=2$ (juta euro) } \\
\hline $\mathbf{c}(2,200,300)$ & 107.01 \\
\hline c(2,200,400) & 220.26 \\
\hline$c(2,200,500)$ & 365.13 \\
\hline $\mathbf{c}(2,300,400)$ & 123.09 \\
\hline $\mathbf{c}(2,300,500)$ & 253.36 \\
\hline $\mathbf{c}(2,400,500)$ & 141.59 \\
\hline \multicolumn{2}{|c|}{ Nilai c untuk $\mathrm{t}=3$ (juta euro) } \\
\hline$c(3,300,600)$ & 403.528 \\
\hline$c(3,400,600)$ & 280.0028 \\
\hline$c(3,500,600)$ & 156.477 \\
\hline
\end{tabular}

Langkah selanjutnya adalah mencari solusi bertahap dengan membuat tabel iterasi dari stage $k=4$ sampai dengan $k=1$ atau menggunakan bantuan Maple dengan menggunakan metode Pemrograman Dinamik masalah StageCoach. Sehingga diperoleh shortest part network sebagai berikut

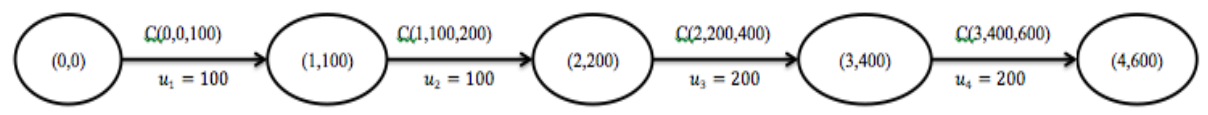

Gambar 2. Shortest Path Network untuk Kasus 1 Tanggul 10

dengan $u_{1}=100 \mathrm{~cm}, u_{2}=100 \mathrm{~cm}, u_{3}=200 \mathrm{~cm}, u_{4}=200 \mathrm{~cm}$.

Maka biaya investasi dan biaya kerusakan yang harus dikeluarkan dengan menggunakan bantuan software Maple adalah sebagai berikut :

$I(u, \tau)=684.70$ juta euro dan $E(u, \tau)=0.72$ juta euro. Maka biaya total yang harus dikeluarkan adalah $f(u, \tau)=E(u, \tau)+I(u, \tau)=685.42$ juta euro.

Kemudian dilakukan cara yang sama untuk kasus 2, kasus 3, kasus 4, dan kasus 5 untuk masing-masing tanggul. Sehingga didapat hasil sebagai berikut :

Tabel 3: Hasil Eksperimen Numerik Tanggul 10 untuk Model Optimisasi Perlindungan Banjir

\begin{tabular}{|c|c|c|c|c|c|}
\hline JJeni & Kasus & 1 Kasus 2 & 2 Kasus 3 & 3 Kasus 4 & 4 Kasus 5 \\
\hline \multirow{4}{*}{$t_{K}:$} & $1: 100$ & $5: 100$ & $10: 100$ & $50: 100$ & $100: 100$ \\
\hline & $2: 100$ & $10: 100$ & $20: 100$ & $100: 100$ & $0200: 100$ \\
\hline & $3: 200$ & $15: 100$ & $30: 100$ & $150: 100$ & $0300: 100$ \\
\hline & $4: 200$ & $20: 300$ & 300 & $: 30$ & $400: 300$ \\
\hline Inv.Co & 684.70 & 423.96 & 240.20 & 14.72 & 1.71 \\
\hline Dam.Co & 0.72 & 3.55 & 6.92 & 2843 & 45.58 \\
\hline Tot.Cost & 685.42 & 427.51 & 247.12 & 43.15 & 47.29 \\
\hline
\end{tabular}


Tabel 4: Hasil Eksperimen Numerik Tanggul 11 untuk Model Optimisasi Perlindungan Banjir

\begin{tabular}{|c|c|r|r|r|r|}
\hline Jenis Kasus & Kasus 1 & Kasus 2 & Kasus 3 & Kasus 4 & Kasus 5 \\
\hline \multirow{3}{*}{$t_{K}: u_{K}$} & $1: 100$ & $5: 100$ & $10: 100$ & $50: 100$ & $100: 100$ \\
\cline { 2 - 6 } & $2: 100$ & $10: 100$ & $20: 100$ & $100: 100$ & $200: 200$ \\
\cline { 2 - 6 } & $3: 100$ & $15: 100$ & $30: 100$ & $150: 100$ & $300: 100$ \\
\cline { 2 - 6 } & $4: 300$ & $20: 300$ & $40: 300$ & $200: 300$ & $400: 200$ \\
\hline Inv.Cost & 1063.67 & 683.90 & 415.05 & 33.49 & 4.04 \\
\hline Dam.Cost & 2.10 & 10.27 & 19.99 & 81.56 & 129.72 \\
\hline Tot.Cost & 1065.77 & 694.17 & 435.04 & 115.05 & 133.76 \\
\hline
\end{tabular}

Tabel 5: Hasil Eksperimen Numerik Tanggul 15 untuk Model Optimisasi Perlindungan Banjir

\begin{tabular}{|c|c|c|c|c|c|}
\hline Jenis Kasus & Kasus 1 & Kasus 2 & Kasus 3 & Kasus 4 & Kasus 5 \\
\hline \multirow{3}{*}{$t_{K}: u_{K}$} & $1: 200$ & $5: 100$ & $10: 100$ & $50: 100$ & $100: 200$ \\
\cline { 2 - 6 } & $2: 200$ & $10: 100$ & $20: 100$ & $100: 100$ & $200: 100$ \\
\cline { 2 - 6 } & $3: 100$ & $15: 200$ & $30: 200$ & $150: 100$ & $300: 100$ \\
\cline { 2 - 6 } & $4: 100$ & $20: 200$ & $40: 200$ & $200: 300$ & $400: 200$ \\
\hline Inv.Cost & 119775.54 & 67794.92 & 31870.76 & 183.76 & 47.24 \\
\hline Dam.Cost & 16.35 & 85.69 & 179.72 & 1351.69 & 4592.33 \\
\hline Tot.Cost & 119791.89 & 67880.61 & 32050.48 & 1535.45 & 4639.57 \\
\hline
\end{tabular}

Tabel 6: Hasil Eksperimen Numerik Tanggul 16 untuk Model Optimisasi Perlindungan Banjir

\begin{tabular}{|c|c|c|c|c|c|}
\hline Jenis Kasus & Kasus 1 & Kasus 2 & Kasus 3 & Kasus 4 & Kasus 5 \\
\hline \multirow{3}{*}{$t_{K}: u_{K}$} & $1: 200$ & $5: 100$ & $10: 100$ & $50: 100$ & $100: 200$ \\
\cline { 2 - 6 } & $2: 200$ & $10: 100$ & $20: 100$ & $100: 100$ & $200: 100$ \\
\cline { 2 - 6 } & $3: 100$ & $15: 200$ & $30: 200$ & $150: 100$ & $300: 100$ \\
\cline { 2 - 6 } & $4: 100$ & $20: 200$ & $40: 200$ & $200: 300$ & $400: 200$ \\
\hline Inv.Cost & 298778.66 & 162436.65 & 76255.83 & 427.76 & 105.43 \\
\hline Dam.Cost & 25.30 & 133.31 & 283.50 & 2421.58 & 10181.19 \\
\hline Tot.Cost & 298803.96 & 162569.96 & 76539.33 & 2849.34 & 10286.62 \\
\hline
\end{tabular}

Tabel 7: Hasil Eksperimen Numerik Tanggul 22 untuk Model Optimisasi Perlindungan Banjir

\begin{tabular}{|c|c|c|c|c|c|}
\hline Jenis Kasus & Kasus 1 & Kasus 2 & Kasus 3 & Kasus 4 & Kasus 5 \\
\hline \multirow{3}{*}{$t_{K}: u_{K}$} & $1: 100$ & $5: 100$ & $10: 100$ & $50: 100$ & $100: 200$ \\
\cline { 2 - 6 } & $2: 100$ & $10: 100$ & $20: 100$ & $100: 100$ & $200: 100$ \\
\cline { 2 - 6 } & $3: 200$ & $15: 200$ & $30: 200$ & $150: 100$ & $300: 100$ \\
\cline { 2 - 6 } & $4: 200$ & $20: 200$ & $40: 200$ & $200: 300$ & $400: 200$ \\
\hline Inv.Cost & 20794.11 & 11672.04 & 5787.72 & 93.93 & 24.00 \\
\hline Dam.Cost & 5.42 & 28.42 & 60.37 & 510.04 & 2144.98 \\
\hline Tot.Cost & 20799.53 & 11700.46 & 5848.09 & 603.97 & 2168.98 \\
\hline
\end{tabular}

Berdasakan Tabel 3-7, diketahui bahwa $t_{K}$ merupakan waktu peninggian tanggul dalam satuan tahun, dan $u_{K}$ merupakan besarnya peninggian tanggul dalam satuan $\mathrm{cm}$. Inv.Cost merupakan biaya investasi, 
Dam.Cost merupakan biaya kerusakan, dan Tot.Cost merupakan biaya total. Pada kasus 1 dilakukan peninggian setiap setahun sekali, pada kasus 2 dilakukan peninggian 5 tahun sekali, pada kasus 3 dilakukan peninggian 10 tahun sekali, pada kasus 4 dilakukan peninggian 50 tahun sekali, dan pada kasus 5 dilakukan peninggian 100 tahun sekali.

Berdasarkan eksperimen numerik yang telah dilakukan, diperoleh hasil numerik dengan gambaran kenaikan dan penurunan biaya dapat dilihat pada grafik berikut

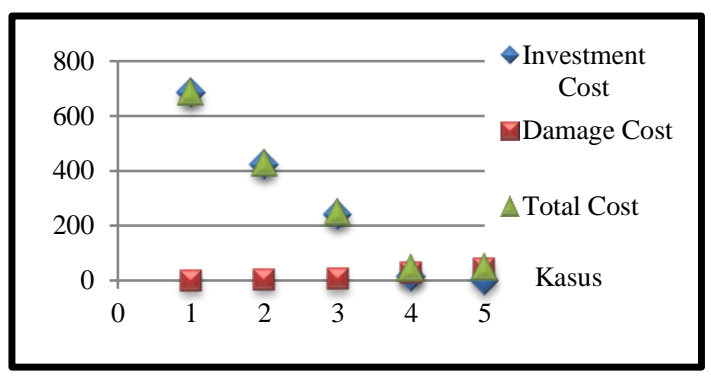

Gambar 3. Grafik Biaya Tanggul 10 untuk Model Optimisasi Perlindungan Banjir

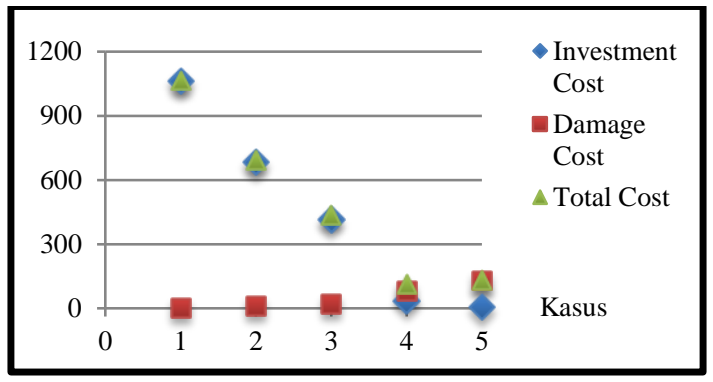

Gambar 4. Grafik Biaya Tanggul 11 untuk Model Optimisasi Perlindungan Banjir

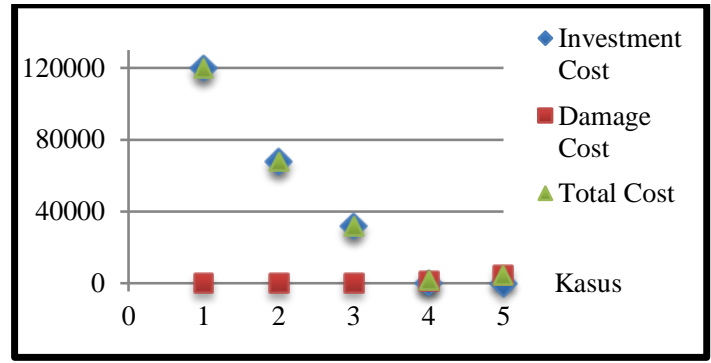

Gambar 5. Grafik Biaya Tanggul 15 untuk Model Optimisasi Perlindungan Banjir

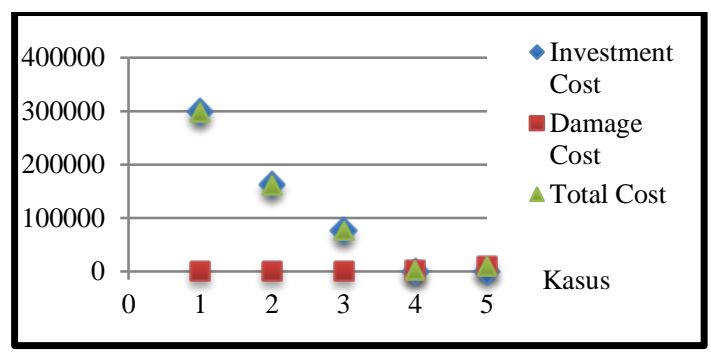

Gambar 6. Grafik Biaya Tanggul 16 untuk Model Optimisasi Perlindungan Banjir 


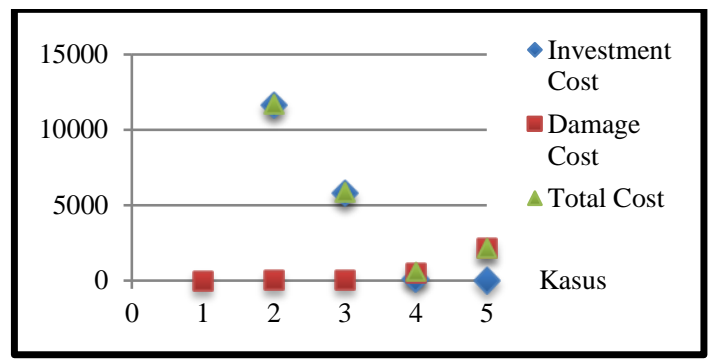

Gambar 7. Grafik Biaya Tanggul 22 untuk Model Optimisasi Perlindungan Banjir

Berdasarkan Gambar 3-7, dapat dilihat bahwa biaya investasi dari kasus 1-5, menurun,. hal ini jelas karena semakin lama melakukan peninggian, biaya pembuatan yang dikeluarkan akan sedikit. Kemudian, dapat dilihat pula bahwa biaya kerusakan dari kasus 1 sampai kasus 5 meningkat, hal ini membuktikan pernyataan van Dantzig (1956) bahwa adanya kenaikan struktur permukaan air setiap waktu yang menyebabkan kerusakan tanggul dan membuat daratan perlahan-lahan tenggelam sehingga menyebabkan kerugian semakin meningkat. Namun, dapat dilihat bahwa biaya total dari kasus 1 sampai kasus 5 tidak monoton turun, maupun monoton naik, karena adanya kenaikan biaya total dari kasus 4 ke kasus 5 . Sehingga jika dilihat dari kasus 1 , kasus 2 , kasus 3 , kasus 4 , dan kasus 5 , berdasarkan fungsi tujuan yang meminimasikan biaya, maka sebaiknya tanggul ditinggikan berdasarkan waktu yang ada pada kasus 4 , yaitu setiap 50 tahun sekali. Namun tidak dipungkiri tanggul dapat ditinggikan lebih dari 50 tahun sekali, dengan syarat biaya total masih kurang dari atau sama dengan nilai biaya total pada kasus 4 untuk masingmasing tanggul.

\section{Simpulan}

Berdasarkan eksperimen numerik yang telah dilakukan dengan diberikannya kasus 1-5, dapat disimpulkan bahwa peninggian tanggul pada kelima kasus ini akan lebih optimal jika ditinggikan dalam kurun waktu 50 tahun sekali karena melihat biaya total yang minimum. Namun sebaiknya penelitian ini dilanjutkan dengan eksperimen pada rentang waktu yang lebih kecil sehingga perubahan total biaya terlihat lebih jelas.

\section{Ucapan Terima Kasih}

Syukur alhamdulillah senantiasa penulis panjatkan kehadirat Allah SWT, yang memiliki keistimewaan dan pemberian segala kenikmatan besar, baik nikmat iman, kesehatan, dan kekuatan dalam penyusunan makalah ini. Salawat serta salam senantiasa tercurah kepada Nabi Muhammad SAW. Pada kesempatan ini penulis menyampaikan rasa terima kasih yang sebesar-besarnya kepada Ibu Dr. Diah Chaerani, M.Si., dan Bapak Dr. juli Rejito, M.Kom., selaku dosen pembimbing yang telah membantu serta memberikan arahan yang amat berharga pada penyusunan paper ini dari proses awal penyusunan hingga paper ini selesai.

\section{Daftar Pustaka}

1. Eijgenraam, C., Brekelmans, R., Hertog, D. d., \& Roos, K. (2012). Flood Prevention by Optimal Dike Heightening. Working Paper, 17.

2. Eijgenraam, C., Brakelmans, R., Hertog, D. d., \& Roos, K. (2010). Safe Dike Heights at Minimal Costs, Part I : The Homogeneous Case.

3. Hertog, D. d., \& Roos, K. (2008, April). Computing Safe Dike Heights at Minimal Costs.

4. Danzig, D. V. (1956). Economic Decision Problems for Flood Prevention. Journal of the Econometric Society, 24 (3), 287.

5. Roos, K. (2009). Mathematical Analysis of the Homogeneous Dike Height Optimization Problem. Tilburg University. 